\title{
Myopathy in acute hypothyroidism
}

\author{
A.W.C. Kung, J.T.C. Ma, Y.L. Yu, C.C.L. Wang, E.K.W. Woo, K.S.L. Lam, C.Y. \\ Huang and R.T.T. Yeung
}

Department of Medicine, University of Hong Kong, Queen Mary Hospital, Pokfulam Road, Hong Kong.

\begin{abstract}
Summary: Hypothyroid myopathy has so far been reported in long standing cases of hypothyroidism. We describe two adult patients with myopathy associated with acute transient hypothyroidism. Both presented with severe muscle aches and cramps, stiffness and spasms. Muscle enzymes were markedly elevated and electromyography in one patient showed myopathic features. Histological changes were absent in muscle biopsy, probably because of the short duration of metabolic disturbance. The myopathy subsided promptly when the hypothyroid state was reversed.
\end{abstract}

\section{Introduction}

Hypothyroid myopathy has been described in patients with long-standing hypothyroidism. ${ }^{1,2,3} \mathrm{We}$ report two Chinese patients with muscle involvement in acute transient hypothyroidism, who improved after reversal of the hypothyroid state.

\section{Case reports}

\section{Case 1}

A 42 year old woman presented at another hospital with a one-month historv of heat intolerance, hand tremors, weight loss, palpitations and sweating. The thyroid gland was diffusely enlarged to two times in size. Her serum thyroxine $\left(\mathrm{T}_{4}\right)$ level was raised at $237 \mathrm{nmol} / 1$ (normal:58-154). Graves' disease was diagnosed and she was treated with carbimazole $30 \mathrm{mg}$ daily together with propranolol $60 \mathrm{mg}$ daily for 4 weeks. She was seen again 6 weeks later and was noted to be clinically euthyroid. The serum $T_{4}$ was $47 \mathrm{nmol} / 1$ and the thyroid stimulating hormone (TSH) raised at $12 \mu \mathrm{IU} / \mathrm{ml}$ (normal up to 7). The dosage of carbimazole was lowered to $20 \mathrm{mg}$ daily and propranolol stopped.

Eight weeks after starting treatment she was referred to our unit because of painful cramps and spasms involving muscles of the shoulder and pelvic girdles. The attacks came on spontaneously or with mild exertion, with severe pain lasting for 10 minutes and gradually wearing off over 2 hours. There was

Correspondence: A.W.C. Kung

Accepted: 3 February 1987 however no muscle weakness or symptoms of hypothyroidism. She had no preceding viral infection. Examination revealed that the goitre had decreased in size and she was clinically euthyroid. Motor and sensory functions were completely normal.

Investigation showed a $\mathrm{T}_{4}$ of $44 \mathrm{nmol} / 1$, triiodothyronine $\left(\mathrm{T}_{3}\right) 1.2 \mathrm{nmol} / 1$ (normal $0.77-2.97 \mathrm{nmol} / 1$ ), and TSH $5.1 \mu \mathrm{IU} / \mathrm{ml}$ (normal up to 7). The serum creatine kinase level was $11,940 \mu \mathrm{mol} / \mathrm{min} .1$ (normal 5-165) and the lactic dehydrogenase was $397 \mu \mathrm{mol} /$ min.1 (normal 130-275), and glutamic-oxalacetic transaminase was $120 \mu \mathrm{mol} / \mathrm{min} .1$ (normal 28-32). Serum sodium and potassium were normal. The trichinella and cysticercosis antibody titres and serial viral antibody titres for viruses likely to cause myositis were negative, as were anti-nuclear antibody, rheumatoid factor, anti-smooth muscle and antistriated muscle antibodies. The ischaemic lactate test showed no abnormality. Electromyography (EMG) was performed on the right deltoid, biceps, vastus medialis and iliopsoas. Myopathic changes were found only in the iliopsoas muscle: a full interference pattern with small spiky polyphasic units less than $500 \mu \mathrm{V}$. A needle biopsy performed over the left deltoid muscle was normal under both light and electron microscopy.

With a low $T_{4}$ level and the exclusion of other causes of painful myopathy, the diagnosis of hypothyroid myopathy was made. Carbimazole was discontinued and within one week, her symptoms subsided, the muscle enzymes returned to normal and thyroid function also became normal $\left(\mathrm{T}_{4}\right.$ of $98 \mathrm{nmol} / 1$ and TSH of $1.2 \mu \mathrm{IU} / \mathrm{ml}$ ). Her thyrotoxic symptoms 
recurred 2 weeks later and carbimazole at $30 \mathrm{mg} /$ day with thyroxine $50 \mu \mathrm{g} /$ day and propranolol $30 \mathrm{mg} /$ day daily was restarted. With this regime, there was no recurrence of the painful myopathy over a follow-up period of 4 months.

\section{Case 2}

A 38 year old man presented with a weight loss of $13 \mathrm{~kg}$ and heat intolerance for 3 months. The thyroid gland was one and a half times enlarged. A diagnosis of Graves' disease was made. Serum $\mathrm{T}_{4}$ was $287 \mathrm{nmol} / 1$ and free thyroxine index (FTI) 284 (normal 76-152). Radioactive iodine $315 \mathrm{MBq}$ was given and he became euthyroid 4 months afterwards. However, $T_{4}$ repeated one year later was $208 \mathrm{nmol} / 1$ with FTI 236 and so a second dose of $150 \mathrm{MBq}$ radioactive iodine was given.

When seen again 6 weeks later, he complained of tiredness and muscle cramps. $T_{4}$ was only $27 \mathrm{nmol} / 1$ with TSH of $1.2 \mu \mathrm{IU} / \mathrm{ml}$. He was admitted 3 days later for severe generalized muscle stiffness and weakness. He was unable to move any of his limbs and the muscle would go into spasm whenever that part was being moved. The spasm was so severe that on one occasion he could not brake his car resulting in a collision. There was clumsiness of movement and weakness of girdle muscles together with myotonic-like reaction. The muscle bulk was increased and all muscles felt stiff and firm. There was delay in relaxation of the bicep and ankle reflexes.

Laboratory investigation revealed elevated muscle enzymes (creatine kinase $7290 \mu \mathrm{mol} / \mathrm{min} .1$ ). Serum $\mathrm{T}_{4}$ was undetectable on two occasions and TSH was $36 \mu \mathrm{IU} / \mathrm{ml}$. EMG of the right deltoid, biceps, vastus medialis and iliopsoas did not reveal myotonia or myopathic changes. The patient refused a muscle biopsy. The clinical picture was compatible with Hoffman's syndrome. Thyroxine was started at $50 \mu \mathrm{g} /$ day together with triiodothyronine $60 \mu \mathrm{g} / \mathrm{day}$. His muscle power showed marked improvement and his muscle cramps and stiffness gradually subsided over one month. The muscle bulk also reverted to normal. Triiodothyronine was stopped 3 months later and the thyroxine dosage was gradually increased to $150 \mu \mathrm{g} /$ day. His thyroid function returned to normal 4 months after the onset of muscle stiffness.

\section{Discussion}

Myopathy is a known complication of long-standing hypothyroidism and the incidence of musculoskeletal symptoms varies from $30-80 \%$ in different series. ${ }^{4,5,6}$ Kocher $^{1}$ and Debre \& Semelaigne ${ }^{2}$ described a syndrome of muscular hypertrophy associated with delayed muscle relaxation in two athyreotic cretins. Hoffman $^{3}$ in 1897 reported an adult who developed stiffness and difficulty in relaxation of muscles with typical myotonic response to contraction, percussion 3 and electrical stimulation after thyroidectomy. In Hoffman's syndrome, the patients typically complain of cramps, ache and pain in muscles of the shoulder and pelvic girdles. They have enlarged muscles, weak $\overline{0}$ ness, slow movements and delayed relaxation of tendon reflexes. Although the Kocher-Debre $\overline{\bar{n}}$ Semelaigne syndrome and Hoffman's syndrome wereळ initially described in different age groups, some authors regard them as variants of the same diseases process. ${ }^{7,8}$

Elevation of the serum creatine kinase in hypothy roidism is common, and the level is proportional tow the degree of the hypothyroid state. ${ }^{9}$ Electromyographic abnormalities are also common with an overals incidence of $61 \% .^{10}$ These usually take the form of myopathic changes with frequent small-amplitude ande short-duration polyphasic motor units on moderate volition. A myotonic-like reaction or pseudomyotonia has rarely been described, being differentiated fromo true myotonia by the absence of the classical waxing and waning characters seen in the latter. ${ }^{7,11}$ The $^{\text {? }}$ mounding phenomenon of myxoedema on percussion $\vec{\longrightarrow}$ of the exposed muscles is electrically silent on EMG. Histologically, muscle fibre enlargement, foca? myofibrillar degeneration, increases in central nuclei, glycogen and mitochondrial aggregates, subsarcolem $-\vec{c}$ mal accumulations of lipofuscin are present. ${ }^{13,14}$ Thereis also dilatation of the sarcoplasmic reticulum aq⿴囗十 proliferation of the T-system. Some authors describeds an increase in Type I fibre area and selective atrophy of Type II fibres, together with low mitochondriaß enzyme activities. The mitochondrial abnormalitiesD are postulated to be due to metabolic disturbances in oxidative phosphorylation. ${ }^{15,16}$ Upon treatment with thyroxine, the symptomatology, creatine phosphokinase, the EMG changes and the muscle morphology all revert back to normal. ${ }^{16,17,18}$

Myopathy may occur in patients with hypoth음 yroidism of idiopathic, ${ }^{19}$ or familial cases ${ }^{20}$ post thyroid irradiation, ${ }^{21}$ post-Hashimoto's thyroiditis, ${ }^{22} 3$ post-thyroidectomy, ${ }^{3}$ and post-radioactive iodines therapy hypothyroidism..$^{23}$ All the cases reported so fars had long duration of hypothyroidism with florid features of myxoedema and a very low $T_{4}$ level. Our two patients had only a short period of biochemicat hypothyroidism -2 weeks in the first and 6 weeks in $=$ the second. Moreover, the degree of hypothyroidism was very mild in the first patient. Thus, while there waș marked elevation of muscle enzymes, EMG only showed mild myopathic changes, and the muscle biopsy was normal. The explanation may be that morphological changes in the muscles have not takerfe place within the short duration of mild hypothyroidism. In a study with rabbit, histological changes cannot be detected till 4 to 8 weeks after thyroidec- $\frac{0}{0}$ 
tomy. ${ }^{24}$ In the second case, although the duration of hypothyroidism was also relatively short, the degree of hypothyroidism was profound and hence the full picture of Hoffman's syndrome was produced. In both patients, the muscle enzymes were markedly elevated when the $T_{4}$ levels ivere low, but returned to normal upon being rendered euthyroid.

Acute transient hypothyroidism is encountered frequently in acute thyroiditis due to lymphocytic thryoiditis or de Quervain's thyroiditis and over-treatment in Graves' disease and Hashimoto thyrotoxicosis. It may also occur immediately after thyroidec-

\section{References}

1. Kocher, T., Zur Verhutung des Cretinismus und cretinoider Zustande nach neuen Forschungen. Dtsch Z Chir 1892, 26: 556-626.

2. Debre, R. \& Semelaigne, G. Syndrome of diffuse muscular hypertrophy in infants causing athletic appearance. Am J Dis Child 1935, 50: 1351-1361.

3. Hoffman, J. Weitere Beitrag zur Lehre von der Tetanie. Dtsch Z Nevenheilkunde (Berlin) 1897, 9: 278-290.

4. Ozker, R.R., Schumacher, O.P. \& Nelson, P.A. Electromyographic finding in adults with myxoedema. Reports of 16 cases. Arch Phys Med Rehabil 1960, 41: 299-370.

5. Astrom, K.E., Kugelberg, E. \& Muller, R. Hypothyroid myopathy. Arch Neurol 1961, 5: 472-482.

6. Collins, J.A., Zimmer, F.E., Johnson, W.J. et al. The many faces of hypothyroidism. Postgrad Med 1964, 36: 371-384.

7. Wilson, J. \& Walton, J.N. Some muscular manifestations of hypothyroidism. J Neurol Neurosurg Psychiat 1959, 22: 320-324.

8. Adams, R.D., Denny-Brown, D. \& Pearson, C.M. In Diseases of Muscle, 2nd edition Harper \& Row, New York, 1962, pp 28-32, 602-603.

9. Graig, F.A.\& Smith, J.C. Serum creatine phosphokinase in altered thyroid states. J Clin Endocrinol Metab 1956, 25: $723-731$.

10. Ramsay, I. Muscular abnormalities of hypothyroidism. In Thyroid Disease and Muscle Dysfunction. William Heinemann, London, 1974, pp 126-171.

11. Thomasen, E. Myotonia. Universitets-forlaget i Aarhus, Copenhagen, 1948: 80-91.

12. Waldstein, S.S., Bronsky, D., Shrifter, H.B. et al. The electromyogram in myxedema. Arch Intern Med 1958, 101: $97-102$.

13. Norris, F.H. \& Panner, B.J. Hypothyroid myopathy. Arch Neurol 1966, 14: 574-589. tomy, or a few months after radioactive iodine therapy for Graves' disease. The majority of these patients tend to be clinically euthyroid, and their thyroid function usually normalises once the thyroid gland has recovered from the insult or when the anti-thyroid drug is withdrawn. We suggest that myopathy in acute transient hypothyroidism is not rare and should be considered as a differential diagnosis of painful myopathy in the appropriate clinical setting. Our patients, particularly the first one, illustrate that the dramatic symptoms of myopathy may be the initial presentation in acute hypothyroidism.

14. Najjar, S.S. \& Nachman, H.S. The Kocher-DebreSemelaigne syndrome. Hypothyroidism with muscular hypertrophy. J. Pediatr 1965, 66: 901-908.

15. McKeran, R.O., Slavin, G., Andrews, T.M., Ward, P. \& Mair, W.G.P. Muscle fibre type changes in hypothyroid myopathy. J Clin Pathol 1975, 28: 659-63.

16. Khaleeli, A.A., Gohil, K. \& PcPhail, G. Round, J.M. \& Edwards, R.H.T. Muscle morphology and metabolism in hypothyroid myopathy: effects of treatment. $J$ Clin Pathol 1983, 36: 519-526.

17. McKeran, R.O., Ward, P., Slavin, G. \& Paul, E.A. Central nuclear counts in muscle fibres before and during treatment in hypothyroid myopathy. J Clin Pathol 1979, 32: 229-233.

18. Griffiths, P.D. Serum enzymes in diseases of the thyroid gland. J Clin Pathol 1985, 18: 660-663.

19. Hesser, F. Hyperthrophia Musculorum Vera associated with hypothyroidism. Bull Johns Hopkins Hosp 1940, 66: 353-377.

20. Perugini, S. \& Prati, P.L. Su due cari familiari di mixedema acquisito decorrenti con distrofia muscolare (myopatla ipotiroidea). Minerva Med 1957, 48: 40604067.

21. Weitz, W: Uber eigentumliche Muskelerscheinungen bie Myxodem (das nach Rontgenbestrahlung und teilweser Strumektomia entstanden war), Dtsch Z Nervenheilk. 1931, 120: 297-303.

22. Goldstone, H. \& Ford, F.R. Severe myotonia as a complication of postoperative thyroid deficiency, Bull Johns Hopkins Hosp 1955, 97: 53-8.

23. Gilbert-Dreyfus, L. Le syndrome myo-hypothyroidien. Hospital (Par.) 1956, 44: 185.

24. Lambert, E.H. \& Sayre, G.P. Myopathy in rabbits following thyroidectomy. Am J Physiol 1955, 183: 636-637. 